\title{
Assessing Potential Functionality of Catechol-0-methyltransferase (COMT) Polymorphisms Associated with Pain Sensitivity and Temporomandibular Joint Disorders
}

\author{
Andrea G. Nackley and Luda Diatchenko
}

\begin{abstract}
Catechol-O-methyltransferase (COMT) is an enzyme that plays a key role in the modulation of catechol-dependent functions such as cognition, cardiovascular function, and pain processing. Recently, our group demonstrated that three common haplotypes of the human COMT gene, divergent in two synonymous and one nonsynonymous position, are associated with experimental pain sensitivity and onset of temporomandibular joint disorder. In order to determine the functional mechanisms whereby these haplotypes contribute to pain processing, a series of in vitro experiments were performed. Haplotypes divergent in synonymous changes exhibited the largest difference in COMT enzymatic activity because of reduced amount of translated protein. The major COMT haplotypes varied significantly with respect to mRNA local stem-loop structures such that the most stable structure was associated with the lowest protein levels and enzymatic activity. Site-directed mutagenesis that eliminated the stable structure restored the amount of translated protein. These data provide the first demonstration that combinations of commonly observed alleles in the coding region of the human COMT gene can significantly affect the secondary structure of corresponding mRNA transcripts, which in turn leads to dramatic alterations in the translation efficiency of enzyme crucial for a variety of essential functions. The protocols applied to the study of these molecular genetic mechanisms are detailed herein.
\end{abstract}

Key words: COMT, Catecholamine, Pain, mRNA secondary structure, Synonymous polymorphism, Haplotype

\section{Introduction}

COMT is an enzyme responsible for degrading catecholamines and thus represents a critical component of homeostasis maintenance (1). The human COMT gene encodes two distinct proteins: soluble COMT (S-COMT) and membrane-bound COMT 
(MB-COMT) through the use of alternative translation initiation sites and promoters. Recently, COMT has been implicated in the modulation of persistent pain such that low COMT activity is associated with heightened pain states $(2-5)$. Our group demonstrated that three common haplotypes of the human COMT gene are associated with pain sensitivity and the likelihood of developing temporomandibular joint disorder (TMD), a common chronic musculoskeletal pain condition (2). Three major haplotypes are formed by three SNPs in the $S$ - and $M B$-COMT coding region at codons his his $^{2}$ (C/T; rs4633), leu ${ }^{136}$ leu (C/G; rs4818), and val ${ }^{158}$ met (A/G; rs4680). Based on subjects' pain responsiveness, haplotypes were designated as low (LPS; CGG), average (APS; TCA), or high (HPS; CCG) pain sensitive. Individuals carrying HPS/APS or APS/APS diplotypes were nearly 2.5 times more likely to develop TMD. The ability to predict the downstream effects of APS and HPS haplotypes is critically important for understanding the molecular basis of catechol-dependent diseases and disorders.

The effects of nonsynonymous polymorphisms have been widely characterized; because these variations directly influence protein function, they are relatively easy to study statistically and experimentally (6). However, characterizing polymorphisms located in regulatory regions, which are much more common, has proved to be problematic (7). Therefore, new strategies are required to study regulatory polymorphisms at transcriptional and translational levels. Here, we focus on the mechanism whereby polymorphisms of the COMT gene regulate gene expression. In silico, mRNA folding was performed to evaluate the effect of LPS, APS, and HPS haplotypes on the stability of the corresponding mRNA secondary structures (8). Subsequent in vitro studies were performed to test the molecular modeling results (8). Full-length $\mathrm{S}$ - and MB-COMT cDNA clones were constructed in mammalian expression vectors that differed only in three nucleotides corresponding to the LPS, APS, and HPS haplotypes. Rat adrenal (PC-12) cells were transiently transfected with each of these six constructs. COMT enzymatic activity, protein expression, and mRNA abundance were measured using enzyme-linked immunosorbent assay (ELISA), Western blot, and real-time polymerase chain reaction (PCR), respectively. Results from these studies demonstrated that the HPS haplotype exhibited a dramatic decrease in COMT enzymatic activity because of increased stability of its corresponding local mRNA stem-loop structure, which in turn resulted in reduced protein, but not mRNA, levels. Additionally, the APS haplotype exhibited a moderate reduction in COMT enzymatic activity because of met allele-dependent decreases in protein thermostability (8). The vigorous set of molecular and cell biologic experiments permitting these conclusions are provided here. 


\section{Materials}

\subsection{Generation of Haplotypic Variants of Human COMT}

2.1.1. Purification and Confirmation of COMT cDNA Constructs
2.1.2. Construction

of $S$ - and MB-COMT

Same Length Constructs
1. Full-length pCMV-SPORT6-based cDNA clones (IMAGE clone collection, BG290167, CA489448, BF037202 BI835796) (Open Biosystems, Huntsville, AL).

2. LB plates containing ampicillin: $25 \mathrm{~g} \mathrm{LB}$ powder and $15 \mathrm{~g}$ agar in $\mathrm{l} \mathrm{L} \mathrm{H}_{2} \mathrm{O}$. Autoclave $25 \mathrm{~min}$, cool to $50^{\circ} \mathrm{C}$, and add $50 \mu \mathrm{g} / \mathrm{mL}$ ampicillin. Pour $35-40 \mathrm{~mL}$ per $10 \mathrm{~cm}$ plate, and dry with lids off for $30 \mathrm{~min}$ in a laminar flow hood. Store dry wrapped plates at $4^{\circ} \mathrm{C}$.

3. LB liquid medium containing ampicillin: $25 \mathrm{~g} \mathrm{LB}$ powder to $1 \mathrm{~L} \mathrm{H}_{2} \mathrm{O}$. Autoclave $25 \mathrm{~min}$ and cool. Store at room temperature and add $50 \mu \mathrm{g} / \mathrm{mL}$ ampicillin just prior to use.

4. QIAprep Spin Miniprep Kit (Qiagen, Valencia, CA).

5. SP6 primer: 5'-GATTTAGGTGACACTATAG-3' (Invitrogen, Carlsbad, CA).

6. COMT-F primer: 5'-TGAACGTGGGCGACAAGAAAGG CAAGAT-3' (Integrated DNA Technologies, Coralville, IA).

7. EndoFree Plasmid Maxi Kit (Qiagen).

8. $50 \%$ glycerol: To prepare, combine 1 part glycerol and 1 part $\mathrm{d}^{2} \mathrm{H}_{2} \mathrm{O}$.

1. Confirmed and purified S- and MB-COMT clones from Subheading 2.1.

2. BspMI restriction enzyme (New England Biolabs, Ipswich, MA).

3. TAE electrophoresis buffer $(50 \times): 121 \mathrm{~g}$ Tris base, $28.5 \mathrm{~mL}$ glacial acetic acid, $18.5 \mathrm{~g} \mathrm{Na}^{2}$ EDTA $2 \mathrm{H}_{2} \mathrm{O}$, and $500 \mathrm{~mL}$ $\mathrm{d}^{2} \mathrm{H}_{2} \mathrm{O}$. To achieve a $\mathrm{l} \times$ TAE buffer working solution, dilute $300 \mathrm{~mL} 50 \times$ TAE buffer with $14.7 \mathrm{~L} \mathrm{~d}^{2} \mathrm{H}_{2} \mathrm{O}$. Store at room temperature.

4. $1.2 \%$ agarose gel: $1.2 \mathrm{~g}$ agarose, $100 \mathrm{~mL} 1 \times$ TAE buffer, $1 \mu \mathrm{L}$ ethidium bromide. Store at room temperature. Prior to use, microwave, stir, and cool at $55^{\circ} \mathrm{C}$ until clear even liquid forms.

5. Prestained $1^{\circ} \mathrm{Kb}$ molecular weight marker (Invitrogen).

6. 10× gel loading buffer (Invitrogen).

7. QIAquick Gel Extraction Kit (Qiagen, Germantown, MD).

8. Shrimp alkaline phosphatase (Roche Applied Science, Indianapolis, IN).

9. Rapid DNA Ligation Kit (Roche Applied Science).

10. Subcloning efficiency DH5 $\alpha$ competent cells (Invitrogen).

11. S.O.C. medium (Invitrogen). 
2.1.3. Construction

of $S$ - and MB-COMT HPS

Constructs with LPS mRNA

Secondary Structure

2.1.4. Construction of $S$ - and MB-COMT HPS

Constructs with APS mRNA Secondary Structure

\subsection{Transient}

Transfection of COMT cDNA Constructs and Isolation of Cell Lysate
1. S- and MB-COMT same length HPS constructs from Subheading 2.2.

2. QuickChange II XL Site-Directed Mutagenesis Kit (Stratagene, LaJolla, CA).

3. HPS Lsm forward and reverse primers: 5'-CACCATCGA

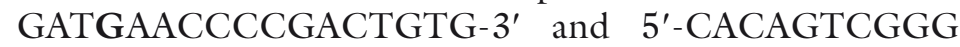
GTTCATCTCGATGGTG-3'， respectively (MWG, High Point, NC,).

4. HPS $\mathrm{dm}$ forward and reverse primers: $5^{\prime}$-CACCCTTG

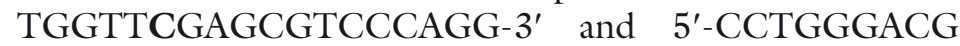
CTCGAACCACAAGGGTG-3', respectively (MWG).

1. S- and MB-COMT same length HPS constructs from Subheading 2.2.

2. PflFl restriction enzyme (New England Biolabs).

3. TAE electrophoresis buffer used in Subheading 2.2.

4. 1.2\% agarose gel used in Subheading 2.2.

5. Prestained $1 \mathrm{~Kb}$ molecular weight marker (Invitrogen).

6. $10 \times$ gel loading buffer (Invitrogen).

7. QIAquick Gel Extraction Kit (Qiagen).

8. Shrimp alkaline phosphatase (Roche Applied Science).

9. HPS Asm 78 base pair oligo and reverse complement: 5'-AGGT CACCCTTGTGGTTGGAGCGTCCC AGGACATCATCCC C C A G C T GA A GA A GA A G T A T GA T G T G GA C ACAGTGGACA- $3^{\prime}$ and $5^{\prime}$-TGTCCACTGTGTCCACAT CATACTTCTTCTTCAGCTGGGGGATGATGTCCT GGGACGCTCCA ACCACAAGGGTGACCT-3', respectively (Integrated DNA Technologies).

10. Rapid DNA Ligation Kit (Roche Applied Science).

1. Rat adrenal PC-12 cells (ATCC, Manassas, VA).

2. PC-12 medium: $250 \mathrm{~mL}$ D-MEM media, $250 \mathrm{~mL}$ Ham's F-12 media, $56 \mathrm{~mL}$ fetal bovine serum (FBS), and $5.6 \mathrm{~mL}$ penicillin-streptomycin. Store at $4^{\circ} \mathrm{C}$ and heat to $37^{\circ} \mathrm{C}$ in a water bath prior to use.

3. $1 \times$ trypsin with EDTA.

4. $1 \times$ phosphate-buffered saline (PBS; Invitrogen).

5. DMSO.

6. Serum-free PC-12 media. Prepare as in step 2 above, omitting the fetal bovine serum.

7. Fugene 6 Transfection Reagent (Roche Applied Science).

8. pSV- $\beta$ Galactosidase vector (Promega, Madison, WI). 


\subsection{Enzymatic Assay for COMT Activity}

\subsection{Western Blotting} for COMT Protein Levels
9. pSEAP2-control (Clonetech, Mountain View, CA).

10. pCMV SPORT 6 empty vector (Invitrogen).

11. $1 \times$ phosphate-buffered saline (Invitrogen).

12. $10 \mathrm{mM}$ trans-1,2-Cyclohexanediaminetetraacetic acid (CDTA; Sigma-Aldrich, St. Louis, MO). Combine $364.35 \mathrm{mg}$ CDTA with $100 \mathrm{~mL} \mathrm{~d}^{2} \mathrm{H}_{2} \mathrm{O}$. Store at $4^{\circ} \mathrm{C}$.

13. Trizol (Invitrogen).

1. Cell lysate in $10 \mathrm{mM}$ CDTA isolated from PC-12 cells in Subheading 2.5.

2. BCA Protein Assay kit (Pierce, Milwaukee, WI).

3. $\beta$ Galactosidase buffer $(2 \times): 542 \mathrm{mg} \mathrm{NaH}_{2} \mathrm{PO}_{4} \cdot \mathrm{H}_{2} \mathrm{O}$, 2,198 $\mathrm{mg} \mathrm{Na}_{2} \mathrm{HPO} 4,40.66 \mathrm{mg} \mathrm{MgCl}_{2}, 134 \mathrm{mg}$ $O$-nitrophenylgalactopyranoside, $1.56 \mathrm{~mL} \beta$-mercaptoethanol with $\mathrm{d}^{2} \mathrm{H}_{2} \mathrm{O}$ up to $100 \mathrm{~mL}$. Make $1.5 \mathrm{~mL}$ aliquots and store at $-20^{\circ} \mathrm{C}$. Thaw to room temperature prior to use.

4. $2 \mathrm{mM} \mathrm{MgCl}_{2}$ in $80 \mathrm{mM}$ PBS: $15.23 \mathrm{mg} \mathrm{MgCL}_{2}, 40 \mathrm{~mL}$ $100 \mathrm{mM} \mathrm{PBS}$, and $10 \mathrm{~mL} \mathrm{~d}^{2} \mathrm{H}_{2} \mathrm{O}$.

5. $7.5 \mathrm{mM}$ L-norepinephrine (NE; Sigma): $26.73 \mathrm{mg} \mathrm{NE}$ is dissolved in $2 \mathrm{~mL} 0.1 \mathrm{M} \mathrm{HCl}$.

6. $6.7 \mathrm{mM} S$-adenosyl-L-methionine (SAMe; ICN Chemicals, Aurora $\mathrm{OH}$ ). First, prepare $1 \mathrm{M}$ sulfuric acid solution by diluting $1 \mathrm{~mL} 18 \mathrm{M} \mathrm{H}_{2} \mathrm{SO}_{4}$ in $17 \mathrm{ml} \mathrm{d}^{2} \mathrm{H}_{2} \mathrm{O}$. Second, prepare a $5 \mathrm{mM}$ sulfuric acid solution by diluting $5 \mathrm{ml} \mathrm{l} \mathrm{M}$ solution in $995 \mathrm{ml} \mathrm{d}^{2} \mathrm{H}_{2} \mathrm{O}$. Finally, combine $3.5 \mathrm{mg}$ SAMe, $900 \mu \mathrm{L} 5 \mathrm{mM} \mathrm{H}_{2} \mathrm{SO}_{4}$, and $100 \mu \mathrm{L} \mathrm{100 \%} \mathrm{ETOH}$ (see Note 1).

7. $0.4 \mathrm{M}$ hydrochloric acid: $40 \mathrm{~mL} 1 \mathrm{M} \mathrm{HCl}$ solution in $60 \mathrm{~mL}$ $\mathrm{d}^{2} \mathrm{H}_{2} \mathrm{O}$.

8. $330 \mu \mathrm{M}$ ethylenedinitrilotetraacetic acid (EDTA): $9.64 \mathrm{mg}$ EDTA is dissolved in $100 \mathrm{~mL} \mathrm{~d}{ }^{2} \mathrm{H}_{2} \mathrm{O}$.

9. Normetanephrine ELISA kit (IBL, Hamburg, Germany).

1. Cell lysate in $10 \mathrm{mM}$ CDTA isolated from PC-12 cells in Subheading 2.5.

2. 10\% Novex Tris-Glycine gels (Invitrogen).

3. Running buffer $(10 \times)$ : $60.6 \mathrm{~g}$ Tris base, $288 \mathrm{~g}$ glycine, $20 \mathrm{~g}$ SDS, and $2 \mathrm{~L} \mathrm{~d}^{2} \mathrm{H}_{2} \mathrm{O}$. $1 \times$ working solution: $1.5 \mathrm{~L}$ of $10 \times$ running buffer is diluted with $13.5 \mathrm{~L} \mathrm{~d}^{2} \mathrm{H}_{2} \mathrm{O}$.

4. Laemmli buffer $(2 \times)$ : $1.88 \mathrm{~g}$ Tris, $2.5 \mathrm{~g} \mathrm{SDS}, 73.75 \mathrm{mg}$ EDTA, $12.5 \mathrm{ml}$ glycerol, and $\mathrm{d}^{2} \mathrm{H}_{2} \mathrm{O}$ to bring up to $100 \mathrm{ml}$. Add a few drops of bromphenol blue and $\mathrm{pH}$ solution to 6.8. Store at room temperature. 
5. $\beta$-mercaptoethanol ( $\beta$ ME; Sigma).

6. SeeBlue pre-stained standard (Invitrogen).

7. Methanol.

8. Transfer buffer $(5 \times): 30.2 \mathrm{~g}$ Tris base, $144 \mathrm{~g}$ glycine, and $2 \mathrm{~L}$ $\mathrm{d}^{2} \mathrm{H}_{2} \mathrm{O}$. To achieve a $\mathrm{l} \times$ working solution, dilute $3 \mathrm{~L}$ of $5 \times$ transfer buffer with $2 \mathrm{~L} \mathrm{~d}^{2} \mathrm{H}_{2} \mathrm{O}$ and add $3 \mathrm{~L}$ methanol.

9. TBST buffer: First, prepare a $2 \mathrm{M}$ Tris stock by combining $121.14 \mathrm{~g}$ Tris base and $500 \mathrm{~mL} \mathrm{~d}^{2} \mathrm{H}_{2} \mathrm{O}$. Second, prepare a $5 \mathrm{M} \mathrm{NaCl}$ stock by combining $146 \mathrm{~g} \mathrm{NaCl}$ in $500 \mathrm{~mL} \mathrm{~d}^{2}$ $\mathrm{H}_{2} \mathrm{O}$. Third, prepare a $5 \times$ stock solution by combining $50 \mathrm{~mL}$ $2 \mathrm{M}$ Tris stock, $300 \mathrm{~mL} 5 \mathrm{M} \mathrm{NaCl}$ stock, $2.5 \mathrm{~mL}$ tween, and $2 \mathrm{~L} \mathrm{~d}^{2} \mathrm{H}_{2} \mathrm{O}$. To achieve a $\mathrm{l} \times$ working solution, dilute $3 \mathrm{~L} 5 \times$ TBST buffer with $12 \mathrm{~L} \mathrm{~d}^{2} \mathrm{H}_{2} \mathrm{O}$.

10. Nitrocellulose membranes (Whatman, Florham Park, NJ).

11. Filter paper backing (Bio-Rad, Hercules, CA).

12. $5 \%$ nonfat milk: $25 \mathrm{~g}$ instant nonfat milk powder in $500 \mathrm{~mL}$ TBST buffer.

13. COMT polyclonal $1^{\circ}$ antibody (Chemicon, Temecula, CA).

14. Goat Anti-Rabbit IgG HRP polyclonal $2^{\circ}$ antibody (1:10, 000; Chemicon).

15. Pierce ECL Western Blotting Substrate (Pierce).

16. Restore western stripping buffer (Pierce).

17. $\beta$-actin polyclonal $1^{\circ}$ antibody (1:10,000; Santa Cruz Biotechnology, Santa Cruz, CA).

18. Goat Anti-Rabbit IgG HRP polyclonal $2^{\circ}$ antibody ( $1: 10,000$; Chemicon).

2.5. Real-Time PCR for COMT Transcript Levels
1. Cell lysate in Trizol isolated from PC-12 cells in Subheading 2.5.

2. Chloroform.

3. Isopropyl alcohol.

4. $75 \%$ ethanol: $75 \mathrm{ml}$ ethanol is diluted with $25 \mathrm{ml} \mathrm{d}^{2} \mathrm{H}_{2} \mathrm{O}$.

5. RNase free $\mathrm{H}_{2} \mathrm{O}$ (Promega).

6. RNase free-DNase I (Promega).

7. Thermo-X reverse transcriptase (Invitrogen).

8. $50 \mu \mathrm{M}$ Oligo $(\mathrm{dT})_{20}$ Primer (Invitrogen).

9. $50 \mathrm{mM}$ EDTA (Invitrogen).

10. DyNAmo-SYBRGreen qPCR kit (MJ Research).

11. SEAP (Clonetech).

12. COMT-F and COMT-R primers: $5^{\prime}$-TGAACGTGGGCGA CAAGAAAGGCAAGAT- ${ }^{\prime}$ and 5'-TGACCTTGTCCTT 
CACGCCAGCGAAAT-3', respectively (Integrated DNA Technologies).

13. SEAP-F and SEAP-R primers: 5'-GCCGACCACTCCC ACGTCTT-3' and 5'-CCCGCTCTCGCTCTCGGTAA-3', respectively (Integrated DNA Technologies).

\section{Methods}

\subsection{Generation of Haplotypic Variants of Human COMT}

A molecular and cell biologic study of human genetic variants requires the generation of corresponding molecular constructs. For variations in the transcribed portion of genes, cDNA expression constructs may often provide comprehensive tools. Although there are a growing number of commercially available sources for cDNA expression constructs, variants of the minor allele are not typically supplied. The common major allele, however, may provide a convenient backbone for necessary constructs.

One such convenient source of full-length cDNA constructs is the NIH initiated I.M.A.G.E. consortium (9). However, even for the COMT gene, which is relatively highly expressed, we were not able to find full-length cDNAs in expression vectors for all the common genetic variants. The presence of entire full-length sequences that include complete $5^{\prime}$ and $3^{\prime}$ untranslated regions (UTRs) was crucial for our studies, as its presence affected the mRNA secondary structure as well as enzymatic activity and protein expression under investigation (8). Thus, we obtained the clones that were available at the time of the study and provided the necessary elements for constructing an entire set corresponding to the three major haplotypes in both $S$ - and $M B-C O M T$ constructs. Although several molecular methods could be applied, we found that the approaches described here were the most efficient for COMT cDNA, which has a high GC content and strong secondary structure.

1. Obtain full-length pCMV-SPORT6-based cDNA clones (10) corresponding to the three COMT haplotypes from the IMAGE clone collection. S-COMT clones BG290167, CA489448, and BF037202 represent LPS, APS, and HPS haplotypes, respectively. The MB-COMT clone BI835796 represents the APS haplotype.

2. Grow clone colonies. First, streak clones on ampicillinresistant $\mathrm{LB}$ plates, invert and grow overnight at $37^{\circ} \mathrm{C}$. Second, select $\sim 10$ colonies, place each in a separate falcon tube containing $5 \mathrm{~mL}$ ampicillin-resistant LB liquid media, and grow overnight in a shaker $(250 \mathrm{RPM})$ at $37^{\circ} \mathrm{C}$. 
3.1.2. Construction

of $S$ - and MB-COMT

Same Length Constructs
3. Purify plasmid DNA corresponding to each selected colony on a small scale as per the QIAprep Spin Miniprep Kit handbook.

4. Confirm purified colony cDNA sequences. First, sequence using SP6 and COMT-F primers as directed by the local sequencing facility. Second, BLAST the result against the GenBank sequence.

5. Purify plasmid DNA corresponding to each of four confirmed constructs on a larger scale. First, expand the confirmed clones by adding $100 \mu \mathrm{L}$ of each (from the starter culture in step 3 ) to separate flasks of $100 \mathrm{~mL} \mathrm{LB}$ liquid media containing ampicillin and allow to grow overnight in a shaker (250 RPM) at $37^{\circ} \mathrm{C}$ ( see Note 2 ). Second, harvest the bacterial cells by centrifugation at $6,000 \times g$ for $15 \mathrm{~min}$ at $4^{\circ} \mathrm{C}$. Finally, proceed with plasmid purification as per the Qiagen Plasmid Purification Handbook.

1. Digest plasmid DNA corresponding to each of the four clones using the unique restriction enzyme BspMI. BspMI will make one cut 37 base pairs before the first SNP (rs4633) and a second cut 123 base pairs after the last SNP (rs4680) in the haplotype (Fig. 1). Optimal cutting is achieved by incubating $10 \mu \mathrm{g}$ DNA with $20 \mu \mathrm{L}$ buffer $3,2.5 \mu \mathrm{L}$ BspMI, and $\mathrm{d}^{2} \mathrm{H}_{2} \mathrm{O}$ up to $200 \mu \mathrm{L}$ at $37^{\circ} \mathrm{C}$ for $4 \mathrm{~h}$.

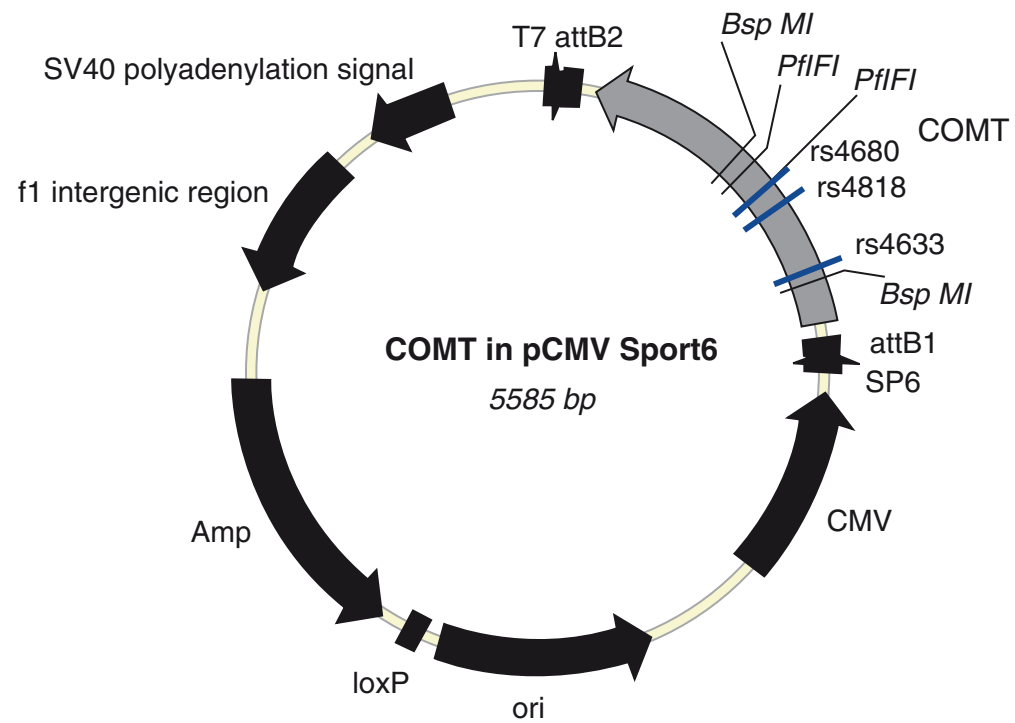

Fig. 1. A schematic illustrates the COMT construct cloned into the pCMV Sport6 vector. pCMV SPORT6-based cDNA clones corresponding to the LPS, APS, and HPS haplotypes were obtained from the IMAGE clone collection. The three SNPs designating LPS, APS, and HPS haplotypes (rs4633, rs4818, and rs4680) are shown in the 1,189 base pair MB-COMT. Additionally, the BspMI and PfIFI restriction sites used to generate COMT same-length constructs and HPS APS-like mutants, respectively, are noted 
2. Isolate $S$ - and MB-COMT vector and haplotype-specific inserts using gel electrophoresis. Prepare a $1.5 \mathrm{~mm}$ thick 1.2\% agarose gel, allow to dry ( $45 \mathrm{~min})$, and cover with TAE electrophoresis buffer. Load well 1 with the prestained $1 \mathrm{~Kb}$ marker and the remaining wells $3,5,7$, and 9 with digested DNA diluted in the $10 \times$ gel loading buffer. Leave wells $2,4,6$, and 8 empty (see Note 3 ). Let the gel run at $100 \mathrm{~V}$ until the $5.3 \mathrm{~Kb}$ vector and 447 base pair insert are clearly separated. Using a razor, excise the vectors (pCMV-SPORT6 vector containing the entire COMT 5' and 3' ends) from the S-COMT clone BG290167 and the MB-COMT clone BI835796. Additionally, excise the inserts (coding region of the gene containing all three haplotype-specific SNPs) from the S-COMT clones BG290167, CA489448, and BF037202. Purify the vectors and inserts as per the Qiagen QIAquick Gel Extraction Kit handbook.

3. Dephosphorylate $S$ - and MB-COMT vectors using shrimp alkaline phosphatase according to the Roche protocol.

4. Ligate $S$ - and MB-COMT vectors and inserts. Specifically, ligate the S-COMT BG290167 vector and the MB-COMT BI835796 vector with each of the BG290167, CA489448, and BF037202 inserts. Use the Rapid DNA Ligation Kit according to the Roche protocol.

5. Clone the 3S-COMT and 3MB-COMT constructs by transforming the corresponding plasmid DNA into subcloning efficiency DH5 $\alpha$ competent cells according to the Invitrogen protocol.

6. Confirm and purify same length constructs as in Subheading 3.1 , steps $2-5$.

3.1.3. Construction

of $S$ - and MB-COMT

Constructs with LPS mRNA

Secondary Structure
1. To make the HPS single and double mutants, perform site-directed mutagenesis using the QuickChange II XL SiteDirected Mutagenesis Kit according to the manufacturer's instructions. To generate the HPS LPS-like single mutant, take the $S$ - and MB-COMT same length HPS constructs and introduce the $403 \mathrm{C}$ to $\mathrm{G}$ mutation in S-COMT and the 625C to G mutation in MB-COMT using HPS Lsm forward and reverse primers.

2. To generate the HPS double mutant, with restored original HPS stem-loop structure, take the HPS LPS-like single mutant and introduce a second $479 \mathrm{G}$ to $\mathrm{C}$ mutation in $\mathrm{S}$-COMT and the $701 \mathrm{G}$ to $\mathrm{C}$ mutation in MB-COMT using HPS dm forward and reverse primers.

3. Clone the HPS LPS-like mutants and double mutants as in Subheading 3.2, step 5.

4. Confirm and purify HPS mutants as in Subheading 3.1, steps $2-5$. 


\subsubsection{Construction}

of $S$ - and MB-COMT

Constructs with APS mRNA

Secondary Structure

\subsection{Transient \\ Transfection of COMT cDNA Constructs and Isolation of Cell Lysate}

1. Digest the S- and MB-COMT same length HPS constructs with the unique restriction enzyme PflFI. PflFI will make one cut 71 base pairs before and a second cut 6 base pairs after the $533 \mathrm{C}$ nucleotide in S-COMT and the $755 \mathrm{C}$ nucleotide in the MB-COMT. Optimal cutting is achieved by incubating $2 \mu \mathrm{g}$ DNA with $5 \mu \mathrm{L}$ buffer $4,0.5 \mu \mathrm{L}$ BSA, $2 \mu \mathrm{L}$ PflFI, and $\mathrm{d}^{2}$ $\mathrm{H}_{2} \mathrm{O}$ up to $50 \mu \mathrm{L}$ at $37^{\circ} \mathrm{C}$ for $\mathrm{l} \mathrm{h}$.

2. Isolate the $\mathrm{S}$ - and $\mathrm{MB}-\mathrm{COMT}$ vectors $(\sim 5 \mathrm{~Kb})$ using gel electrophoresis as in Subheading 3.2, step 2. Purify the vectors as per the Qiagen QIAquick Gel Extraction Kit handbook.

3. Dephosphorylate S- and MB-COMT vectors using shrimp alkaline phosphatase according to the Roche protocol.

4. Ligate S- and MB-COMT vectors with the HPS Asm 78 base pair oligo and reverse complement that contains the $533 \mathrm{C}$ to G substitution in S-COMT and the 755C to G substitution in MB-COMT. Use the Rapid DNA Ligation Kit according to the Roche protocol.

5. Clone the HPS APS-like mutants as in Subheading 3.2, step 5 .

6. Confirm and purify HPS mutants as in Subheading 3.1, steps $2-5$.

A transient transfection is a quick way to deliver expressed gene variants to cells in order to study their potential functional effects. Stable transfection with the variants of interest may be a more robust choice when only the activity of the corresponding protein is altered; however, when expression of the genes is studied, stable transfection results are difficult to interpret as each transfected clone displays different expression levels, largely driven by genetic content at the site of construct insertion. Transient transfection, however, requires tight control for the efficiency of transfection that may drive the observed differences in expression of the variants. We cotransfected the variants of interest with the expression vector for $\beta$ Galactosidase, the activity of which in the cell lysates can be quickly and robustly measured, for activity and protein assays. We also co-transfected the variants of interest with the SEAP vector as a control for transfection efficiency in real-time PCR experiments, as we found SEAP cDNA has a robust quantitative pattern of amplification.

The choice of the cell line for construct transfection can be a very crucial step, as activation of the majority of transduction pathways displays cell-specific characteristics. Thus, the genetic variants under investigation should be tested in the cell system that has an active corresponding pathway. However, endogenous expression of the gene should not be too high, allowing for differences in the transfected endogenous variants' activities to be observed. We generally recommend that several cell lines initially be tested. 
For COMT expression, we found that the PC-12 cell line, a widely used model of neuronal cells, provided the best test system.

1. Plate frozen rat adrenal PC-12 cells. Place a $1 \mathrm{~mL}$ aliquot of frozen cells in FBS and DMSO (see Note 4) in a $37^{\circ} \mathrm{C}$ water bath until thawed ( $\sim \mathrm{min})$ and then add to $9 \mathrm{~mL} \mathrm{PC}-12$ media in a $100 \mathrm{~mm}$ dish. Change media after cells adhere ( 1-2 h).

2. Passage cells. When cells become confluent, aspirate media, wash cells with $1 \times \mathrm{PBS}$, add $1 \mathrm{~mL}$ trypsin, and gently rock so trypsin covers the plate. Place the dish in a $37^{\circ} \mathrm{C}$ incubator for 3-5 min or until cells move freely when dish is gently tapped. Add $10 \mathrm{~mL}$ fresh media to the cells and gently pipette up and down ( 10 times) to break up clumps of cells. Plate cells at a $1: 10$ dilution by adding $1 \mathrm{~mL}$ cells to $9 \mathrm{~mL}$ media in a $100 \mathrm{~mm}$ dish. Passage cells $\sim 2-3$ times to establish normal growth prior to experiment. It is important to note that cell passage number significantly affects experimental results (Fig. 2). Thus, we do not recommend using cells with passage number exceeding 40 .

3. Prepare cells for transfection. When passaging cells immediately prior to transfection, plate them in $35 \mathrm{~mm}$ 6-well dishes with $2 \mathrm{~mL}$ media per well. Prepare enough dishes to account for duplicates for enzymatic activity, and protein expression assays (in which cells are collected in $10 \mathrm{mM}$ CDTA) and RNA

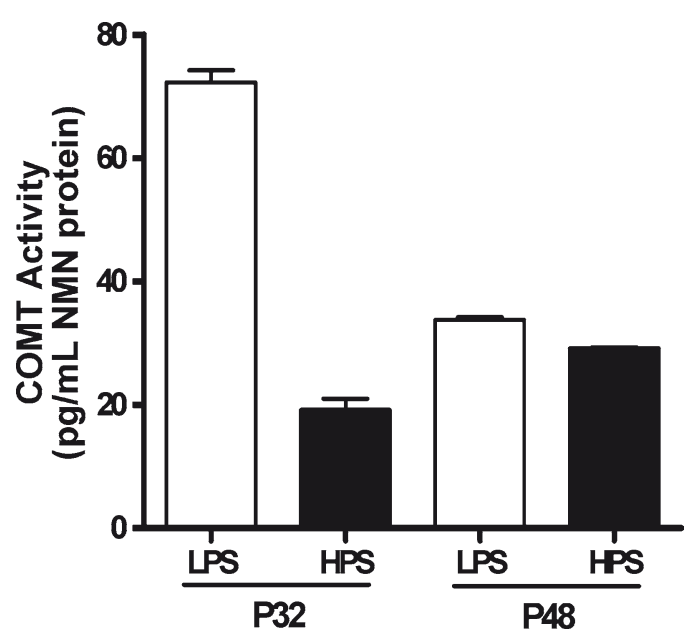

Fig. 2. The PC-12 cell passage number at the time of transfection affects COMT enzymatic activity. PC-12 cells from ATCC were acquired through the UNC tissue culture facility at passage 30 (P30). Younger cells used closer to this passage time demonstrated significant haplotype-dependent differences in S-COMT enzymatic activity relative to older cells that were passaged numerous times. As illustrated above, the LPS haplotype exhibited a fourfold increase in activity compared with the HPS haplotype when constructs were transfected in P32 cells. However, no differences between LPS and HPS haplotypes were found when the constructs were transfected in P48 cells. Data represent Mean \pm SEM 
3.3. Enzymatic Assay for COMT Activity abundance assays (in which cells are collected in Trizol). One hour prior to transfection, remove $1 \mathrm{~mL}$ media per well so that only $1 \mathrm{~mL}$ media remains.

4. Transfect cells. A 1:10 split of PC-12 cells will provide experimental cultures that are approaching optimal $60-70 \%$ confluence after $12 \mathrm{~h}$. Combine COMT plasmid $(2 \mu \mathrm{g} /$ well $)$ and control bGalactosidase and SEAP cDNA plasmids for transfection efficiency $(0.1 \mu \mathrm{g}$ each/well). Transiently transfect cells using SuperFect Reagent in accordance with manufacture's recommendations. Transfection with the pCMV SPORT 6 vector lacking the insert should be done for each experiment. Change media $\sim 12 \mathrm{~h}$ following transfection.

5. Collect cell lysates $\sim 40$ h posttransfection. To collect cells for measurement of enzymatic activity and protein expression, remove media, wash cells 2 times with PBS ( $2 \mathrm{~mL}$ per well), then add $300 \mu \mathrm{L} 10 \mathrm{mM}$ CDTA per well, and store dishes at $-80^{\circ} \mathrm{C}$. To collect cells for measurement of RNA abundance, remove media, add $500 \mu \mathrm{L}$ Trizol per well, pipette several times to remove all adherent cells, transfer cells in Trizol to $1.7 \mathrm{~mL}$ conical tubes, and store at $4^{\circ} \mathrm{C}$ (see Note 5 ).

The assay for biologic activity of the gene product is the most relevant for assessing the potential functionality of genetic variants. It is also most difficult for generalization, as the majority of gene products require their own specific assay depending on the nature of their biological activity. As COMT methylates catecholamines, we developed an enzymatic assay that applies the ELISA for measuring the amount of normetanephrine (NMN) in cell lysates. Although there are other approaches to measure methylated catecholamines with even higher sensitivity, such as HPLC, commercial availability of the ELISA for NMN provides significant convenience. The ELISA measuring metanephrine and metadopamine can also be used for the assessment of COMT enzymatic activity.

1. Lyse cells collected in $10 \mathrm{mM}$ CDTA by repeatedly freezing/ thawing five times at $-80^{\circ} \mathrm{C}$ and room temperature, respectively. Collect the cells in $1.7 \mathrm{~mL}$ tubes, centrifuge at $2,000 \times \mathrm{g}$ for $10 \mathrm{~min}$, and remove filtrate.

2. Normalize for protein concentration using the Pierce BCA kit according to the Pierce protocol.

3. Evaluate transfection efficiency. Combine $50 \mu \mathrm{L}$ normalized cell lysate from step 2 with $50 \mu \mathrm{L} 2 \times \beta$ Galactosidase buffer in a clear $96-$ well plate and incubate at $37^{\circ} \mathrm{C}$ for $20-30 \mathrm{~min}$ or until lysate begins to turn yellow. Quantify absorbance using a luminometer with a $405 \mathrm{nM}$ filter (see Note 6). 
4. The COMT enzymatic assay is based on the method described by Masuda's group (11). Purified lysates $(8 \mu \mathrm{l})$ are incubated with $11 \mu \mathrm{l} 2 \mathrm{mM} \mathrm{MgCl}_{2}$ in $80 \mathrm{mM}$ PBS, $0.5 \mu \mathrm{l} 7.5 \mathrm{mM} \mathrm{NE}$, $0.5 \mu \mathrm{l} 6.7 \mathrm{nM}$ SAMe, and $1 \mu \mathrm{d} \mathrm{d}^{2} \mathrm{H}_{2} \mathrm{O}$ for $60 \mathrm{~min}$. The reaction is terminated using $20 \mu \mathrm{l}$ of $0.4 \mathrm{M} \mathrm{HCl}$ and $1 \mu \mathrm{l}$ of $330 \mathrm{mM}$ EDTA. The same reaction in the presence of $15 \mathrm{mM}$ EDTA should be carried out in parallel for each lysate to bind $\mathrm{Mg}^{+2}$ ions required for COMT activity - this provides a negative control.

5. COMT activity is assessed as measurement of NMN by Normetanephrine ELISA kit in accordance with manufacture's recommendations using $10 \mu \mathrm{l}$ of reaction mixture from step 3 above. COMT activity is determined after subtracting the amount of NMN produced by endogenous enzymatic activity (transfection with empty vector). COMT activity is then normalized for transfection efficiency based on $\beta$-galactosidase activity quantified for each lysate.

3.4. Western Blotting for COMT Protein Levels
As one finds that genetic variants alter activity of the corresponding protein, the next critical question is the level of the regulation. To determine if genetic variants differentially control gene expression at the level of translation, relative protein amounts should be measured. Probably the most common approach is the Western blot analysis described here.

1. Prepare a $10 \%$ Novex Tris-Glycine gel by washing individual wells with running buffer. Assemble the gel in Western electrophoresis chamber. Fill chamber with running buffer and then wash individual wells with running buffer a second time by gently pipetting up and down several times. Importantly, remove any bubbles remaining in wells with a pipette tip.

2. Prepare purified lysates normalized for protein concentration obtained in Section 3.3, step 2. Dilute samples (10-50 $\mathrm{gg}$ per well) in $2 \times$ Laemmli buffer and $5 \% \beta \mathrm{ME}$ (e.g., $95 \mu \mathrm{L}$ Laemmli buffer and $5 \mu \mathrm{L} \beta \mathrm{ME}$ ) for a final volume of $30 \mu \mathrm{L}$ (see Note 7). Vortex samples and boil for $5 \mathrm{~min}$ at $95^{\circ} \mathrm{C}$ to denature proteins.

3. Run protein samples. Load $\sim 7 \mu \mathrm{L}$ SeeBlue marker in well 1 and $30 \mu \mathrm{L}$ of samples in Laemmli buffer in the remaining wells. Add Laemmli buffer to any remaining empty wells. Run the gel at $90 \mathrm{~V}$ for $2 \mathrm{~h}$ or $80 \mathrm{~V}$ for $3 \mathrm{~h}$ (see Note 8 ).

4. Transfer protein samples from the gel to a nitrocellulose membrane. In advance, soak the membrane in methanol and the transfer sponges and filter paper in transfer buffer for 5-10 min. Prepare a "transfer sandwich" in a shallow plastic container filled with transfer buffer by placing the transfer cassette bottom-side down then layering (1) 1 sponge, (2) several sheets of filter paper, (3) gel removed from plastic 
3.5. Real-Time PCR for COMT Transcript Levels case, (4) membrane, (5) several sheets of filter paper, and (6) l sponge. Importantly, make sure there are no bubbles between the gel and membrane (see Note 9). Close the cassette and place it in the transfer chamber so the gel side is toward the cathode and the membrane side is toward the anode. Place a magnetic stir bar at the bottom in the middle of the chamber, add the ice bucket, and fill chamber with transfer buffer. Run on magnetic mixer at $85 \mathrm{~V}$ for $2 \mathrm{~h}$ or $25 \mathrm{~V}$ overnight at $4^{\circ} \mathrm{C}$.

5. Stain the membrane for COMT protein. Rinse the membrane with TBST buffer and then, block it in $5 \%$ nonfat milk for $\mathrm{l} \mathrm{h}$ at room temperature. Wash the membrane three times for 5 min each in TBST at room temperature. Incubate the membrane with COMT polyclonal $1^{\circ}$ antibody overnight at $4^{\circ} \mathrm{C}$ and then with Goat Anti-rabbit IgG HRP polyclonal $2^{\circ}$ antibody for $\mathrm{l} \mathrm{h}$ at room temperature.

6. Measure COMT protein. Wash the membrane with TBST for $10 \mathrm{~min}$ at room temperature and then expose it to western blotting substrate as per Pierce's guidelines. Cover the membrane in plastic and then measure electrochemiluminescence using the GE ImageQuant or similar imager.

7. Verify equal loading of samples by measuring $\beta$-actin. Strip the membrane using Restore western stripping buffer, wash two times for 15 each in TBST, and block in $5 \%$ nonfat milk for $30 \mathrm{~min}$ at room temperature. Incubate the membrane with $\beta$-actin polyclonal $1^{\circ}$ antibody for $\mathrm{l} \mathrm{h}$ at room temperature followed by Goat Anti-Rabbit IgG HRP polyclonal $2^{\circ}$ antibody for $\mathrm{l} \mathrm{h}$ at room temperature. Measure $\beta$-actin protein as in step 7 above.

If expression levels of the variants are altered at the protein level, it is highly likely that these differences are driven by differences in mRNA transcription. Expression constructs are not suitable for studying differences in transcription efficiency because they contain an artificial strong viral promoter instead of a natural promoter of the gene under investigation. To study genetic variants that alter transcription, corresponding variant promoter regions should be cloned in one of the reporter vectors that allow the study of transcription efficiency. However, expression constructs may display different mRNA levels due to difference in mRNA degradation rates. An application of real-time PCR for measuring mRNA levels that is much more efficient than alternative approaches such as Northern blot analysis or $5^{\prime}$ extension assay is described here. However, as we show here, the experimenter should be aware that relative abundance of the amplified regions reflects relative abundance of corresponding mRNA only if genetic variants do not differentially affect cDNA synthesis or PCR efficiency. 
In the case of COMT, we show that genetic variants possess alternative secondary structures that affect the efficiency of transcription in the condition routinely used for cDNA synthesis and require specific reverse transcriptases and enzymatic reaction conditions that are insensitive to mRNA secondary structures.

1. Isolate RNA. Take $1.7 \mathrm{~mL}$ tube of cells collected in Trizol from Subheading 3.5, step 5. Add $200 \mu \mathrm{L}$ chloroform, vortex $\sim 1 \mathrm{~min}$, and centrifuge at $13,000 \times \mathrm{g}$ for $15 \mathrm{~min}$ at $4^{\circ} \mathrm{C}$. The RNA is present in the top colorless aqueous phase. Transfer the aqueous phase to a new $1.7 \mathrm{~mL}$ tube, add $500 \mu \mathrm{L}$ isopropyl alcohol, vortex, incubate $10 \mathrm{~min}$ at room temperature, and centrifuge at $13,000 \times \mathrm{g}$ for $10 \mathrm{~min}$ at $4^{\circ} \mathrm{C}$. RNA appears as a gel-like pellet on the side of the tube towards the bottom. Remove supernatant, add $1 \mathrm{~mL} 75 \%$ ethanol, vortex, and centrifuge at 7,500 $\times$ g for $5 \mathrm{~min}$ at $4^{\circ} \mathrm{C}$. Remove supernatant and allow RNA pellet to dry ( $\sim 20 \mathrm{~min})$. Reconstitute dry pellet in $\sim 30 \mu \mathrm{L}$ RNase-free $\mathrm{H}_{2} \mathrm{O}$ to achieve a concentration of $\sim 800$ $1,600 \mathrm{ng} / \mu \mathrm{L}$. Use a spectrometer to determine final RNA concentration and store RNA at $-80^{\circ} \mathrm{C}$ until ready to use. Note that the length of time the samples remain in Trizol prior to purification will affect the total amount of RNA (Fig. 3).

2. Purify RNA with RNase-free-DNase I according to the Promega protocol.

3. Perform first strand cDNA synthesis using Thermo-X reverse transcriptase according to a modified version of the Invitrogen protocol. For the annealing step, combine the RNA sample

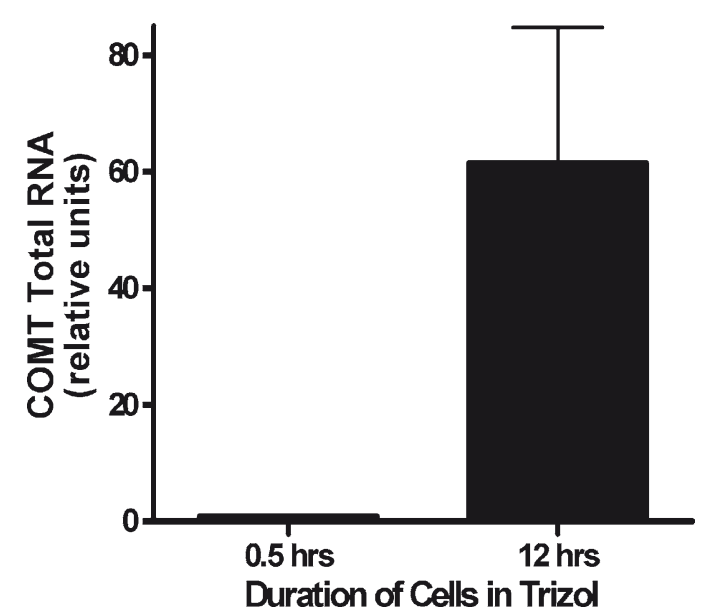

Fig. 3. The duration of PC-12 cells in Trizol prior to purification affects RNA abundance. Cells transfected with S-COMT constructs were incubated in Trizol for either 0.5 or $12 \mathrm{~h}$ prior to isolation of total RNA. Cells incubated in Trizol for $12 \mathrm{~h}$ at $4^{\circ} \mathrm{C}$ exhibited an approximately 60 -fold increase in RNA yield relative to cells incubated in Trizol for only $0.5 \mathrm{~h}$. Data represent Mean \pm SEM 
( $1 \mathrm{ng}$ to $5 \mu \mathrm{g}$ ), $1 \mu \mathrm{L} 50 \mu \mathrm{M}$ Oligo(dT) ${ }_{20}, 1 \mu \mathrm{L} 10 \mathrm{mM}$ dNTP mix, and nuclease-free $\mathrm{H}_{2} \mathrm{O}$ for a final volume of $10 \mu \mathrm{L}$. Mix, incubate for $5 \mathrm{~min}$ at $65^{\circ} \mathrm{C}$, and then cool on ice for $1 \mathrm{~min}$ or longer. For the extension step, add the following to each tube of annealed RNA: $4 \mu \mathrm{L}$ Thermo-X buffer, $5 \mu \mathrm{L}$ nuclease free $\mathrm{H}_{2} \mathrm{O}$, and $1 \mu \mathrm{L}$ Thermo-X reverse transcriptase. Mix, incubate for $30 \mathrm{~min}$ at $64^{\circ} \mathrm{C}$, add $2 \mu \mathrm{L} 50 \mathrm{mM}$ EDTA, incubate for $5 \mathrm{~min}$ at $90^{\circ} \mathrm{C}$. Store samples at $-20^{\circ} \mathrm{C}$ until ready to use. Prior to real-time $\mathrm{PCR}$, dilute samples $1: 10$ in nuclease-free $\mathrm{H}_{2} \mathrm{O}$. Note that the type of reverse transcriptase used may affect real-time PCR results (Fig. 4).

4. Prepare COMT and SEAP standards for real-time PCR. To prepare the COMT standards, first prepare a $100 \mathrm{pg} / \mathrm{mL}$ stock solution from one of the purified COMT constructs. Then, make 5 fivefold serial dilutions $(20 \mu \mathrm{L} 100 \mathrm{pg} / \mathrm{mL}$ plasmid diluted in $80 \mu \mathrm{L}$ TE buffer $=20 \mu g / m L, 20 \mu L 20 \mu g / m L$ plasmid diluted in $80 \mu \mathrm{L} \mathrm{TE}$ buffer $=4 \mathrm{pg} / \mathrm{mL}$, etc.) to yield a total of 7 standards: $100,20,4,0.8,0.16,0.04$, and $0 \mathrm{pg} / \mathrm{mL}$. To prepare the SEAP standards, first make a $50 \mathrm{pg} / \mathrm{mL}$ stock solution from the Clonetech SEAP plasmid. Then, make 5 fivefold serial dilutions $(20 \mu \mathrm{L} 50 \mathrm{pg} / \mathrm{mL}$ plasmid diluted in $80 \mu \mathrm{L}$ TE buffer $=10 \mathrm{pg} / \mathrm{mL}, 20 \mu \mathrm{L} 10 \mathrm{pg} / \mathrm{mL}$ plasmid diluted in $80 \mu \mathrm{L}$ TE buffer $=2 \mathrm{pg} / \mathrm{mL}$, etc.) to yield a total of 7 standards: $50,10,2,0.4,0.08,0.016$, and $0 \mathrm{pg} / \mathrm{mL}$.

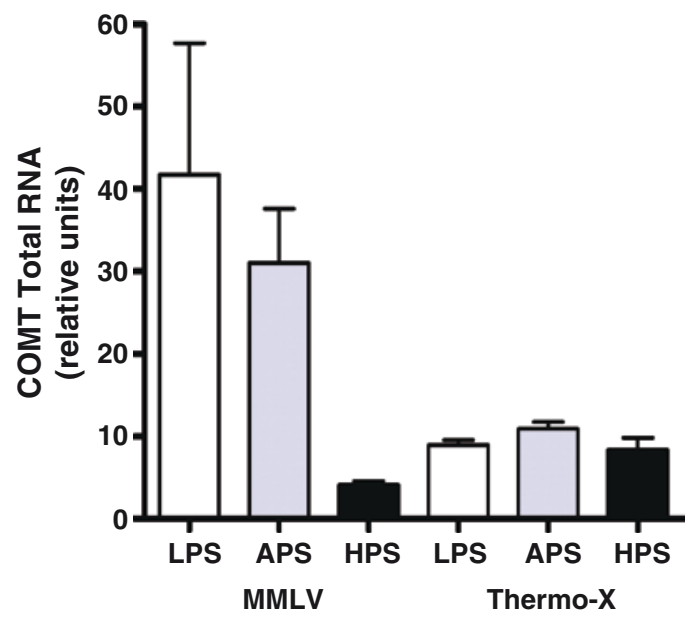

Fig. 4. RNA secondary structure influences the ability of reverse transcriptase to synthesize cDNA. First strand synthesis performed using MMLV reverse transcriptase yields an artificial tenfold difference observed in relative RNA abundance between the S-COMT LPS and HPS haplotypes. This artificial difference driven by the more stable secondary structure associated with the HPS haplotype $(8,12)$ was eliminated when first strand synthesis was performed using Thermo- $X$, which is a reverse transcriptase designed to synthesize CDNA from more challenging templates with high GC content or extensive secondary structure. Data represent normalized Mean values \pm SEM 
5. Prepare real-time PCR pates. Each RNA sample is tested for both COMT (experimental sample) and SEAP (experimental control) mRNA amount. For each COMT sample, standard, or negative control well, combine $12 \mu \mathrm{L}$ SYBR Green dye, $0.5 \mu \mathrm{L} 20 \mu \mathrm{M}$ COMT-F primer, $0.5 \mu \mathrm{L} 20 \mu \mathrm{M}$ COMT-R primer, $5 \mu \mathrm{L}$ nuclease-free $\mathrm{H}_{2} \mathrm{O}$, and $2 \mu \mathrm{L}$ template from step 3 or $2 \mu \mathrm{L}$ standard from step 4 . For each SEAP sample or standard well, combine the same ingredients but substitute SEAP-F and SEAP-R for COMT-F and COMT-R primers (see Note 10). After filling the wells, spin the plate so that no bubbles remain, and then carefully cap the wells.

6. Perform real-time PCR. Enter the following routine in the PCR machine: Step 1: Initial denaturation $95^{\circ} \mathrm{C}$ for $12 \mathrm{~min}$, Step 2: Denaturation $95^{\circ} \mathrm{C}$ for $30 \mathrm{~s}$, Step 3: Annealing $55^{\circ} \mathrm{C}$ for $30 \mathrm{~s}$, Step 4: Extension $71^{\circ} \mathrm{C}$ for $30 \mathrm{~s}$, Step 5: Read, Step 6: Repeat cycles two to four 40 times, Step 7: Incubate $10^{\circ} \mathrm{C}$ forever, and Step 8: End. Calculate COMT mRNA abundance for each sample and then normalize for transfection efficiency based on SEAP mRNA abundance (see Note 11).

\section{Notes}

1. SAMe is very unstable, even stored as powder at $-80^{\circ} \mathrm{C}$. The half life is $30 \mathrm{~min}$ at room temperature and activity diminishes rapidly with repeated freeze thawing. Over time, the white powder turns to a brown "glue" that is no longer usable.

2. After growing plasmids and prior to purification, it is important to save an aliquot of each plasmid for long-term storage. Place $1 \mathrm{ml}$ of plasmid in a cryo-safe tube and add $150 \mu \mathrm{L}$ of $50 \%$ glycerol to achieve a final dilution of $7 \%$ glycerol. Gently mix by inverting the tube several times, then store in liquid nitrogen.

3. When purifying DNA from agarose gel, it is important to leave wells between samples empty in order to prevent cross-contamination that may occur when cutting bands close together.

4. After passaging cells 2-3 times, it is important to save aliquots for long-term storage. Once cells are confluent, trypsinize them, collect in $1 \mathrm{~mL}$ PC-12 media, and place in a $15 \mathrm{~mL}$ tube. Add $8 \mathrm{~mL}$ FBS and $1 \mathrm{~mL}$ DMSO. Mix well by gently pipetting several times and aliquot $1 \mathrm{~mL}$ cells per cryotube. Store in liquid nitrogen.

5. Cells can remain in Trizol at $4^{\circ} \mathrm{C}$ for up to 2 weeks. If a longer storage time is needed prior to purification of RNA, place cells in Trizol solution at $-80^{\circ} \mathrm{C}$, where they can remain indefinitely. 
6. Obtaining a relative measure of transfection efficiency for each sample is important as it allows for normalization of enzymatic assay results. If transfection efficiency is low, the incubation time may need to be extended for several hours or even overnight.

7. For best results, do not store Laemmli buffer with $\beta$-mercaptoethanol.

8. If protein bands do not run evenly on the gel, it could be due to an expired gel, low level of buffer, or too high a voltage.

9. Air bubbles between the gel and membrane will disrupt the transfer of protein. To eliminate bubbles, gently force them to the closest edge of the gel. Test tubes, pipettes, or gel rollers may also be used for this purpose.

10. To achieve the most uniform results, calculate the total number of COMT standard, SEAP standard, COMT sample, and SEAP sample wells required for the experiment and prepare COMT and SEAP master mixes that contain enough dye, appropriate primer, and water for that total number of wells. Pipette $18 \mu \mathrm{L}$ master mix in each well, then add $2 \mu \mathrm{L}$ sample to the master mix in each well. For a standard experiment, estimate running duplicate wells for 7 COMT standards, 7 SEAP standards, and single wells for DNase-treated RNA samples that did not undergo first strand cDNA synthesis (negative control). The remaining wells can be used to amplify COMT or SEAP for each experimental sample in duplicate.

11. The experiments studying differences in mRNA levels can be modified for more exact identification of mRNA degradation rates. Actinomycin D, a nonspecific inhibitor of mRNA transcription, should be added to cells transfected with the variants under investigation, several time points collected, and RNA isolated and measured by real-time PCR as described above.

\section{Acknowledgments}

The authors would like to thank Dr. Inna Tchivileva and Katherine Satterfield for their help in developing the HPS LPS-like and HPS APS-like mutants and Drs. Svetlana Shabalina and William Maixner for their support in the development of these studies. Additionally, the authors would like to thank IBL Hamburg for their generous gift of normetanephrine ELISA kit components. This work was supported by the NIH/NCRR KL2-RR025746 and NIH/OBSSR R24-DK067674 awards to Andrea Nackley and the NIH/NIDCR R0l-DE016558, POl-NS065685, and U01-DE017018 awards Luda Diatchenko. 


\section{References}

1. Mannisto PT, Kaakkola S (1999) Catechol$O$-methyltransferase (COMT): biochemistry, molecular biology, pharmacology, and clinical efficacy of the new selective COMT inhibitors. Pharmacol Rev 51:593-628

2. Diatchenko L, Slade GD, Nackley AG, Bhalang K, Sigurdsson A, Belfer I, Goldman D, Xu K, Shabalina SA, Shagin D et al (2005) Genetic basis for individual variations in pain perception and the development of a chronic pain condition. Hum Mol Genet 14:135-143

3. Marbach JJ, Levitt M (1976) Erythrocyte catechol-O-methyltransferase activity in facial pain patients. J Dent Res 55:711

4. Rakvag TT, Klepstad P, Baar C, Kvam TM, Dale O, Kaasa S, Krokan HE, Skorpen F (2005) The Vall58Met polymorphism of the human catechol- $O$-methyltransferase (COMT) gene may influence morphine requirements in cancer pain patients. Pain 116:73-78

5. Zubieta JK, Heitzeg MM, Smith YR, Bueller JA, Xu K, Xu Y, Koeppe RA, Stohler CS, Goldman D (2003) COMT vall58met genotype affects mu-opioid neurotransmitter responses to a pain stressor. Science 299: 1240-1243

6. Yampolsky LY, Kondrashov FA, Kondrashov AS (2005) Distribution of the strength of selection against amino acid replacements in human proteins. Hum Mol Genet 14:3191-3201
7. Knight JC (2005) Regulatory polymorphisms underlying complex disease traits. J Mol Med 83:97-109

8. Nackley AG, Shabalina SA, Tchivileva IE, Satterfield K, Korchynskyi O, Makarov SS, Maixner W, Diatchenko L (2006) Human catechol-O-methyltransferase haplotypes modulate protein expression by altering mRNA secondary structure. Science 314:1930-1933

9. Lennon G, Auffray C, Polymeropoulos M, Soares MB (1996) The I.M.A.G.E. Consortium: an integrated molecular analysis of genomes and their expression. Genomics 33:151-152

10. Strausberg RL, Feingold EA, Grouse LH, Derge JG, Klausner RD, Collins FS, Wagner L, Shenmen CM, Schuler GD, Altschul SF et al (2002) Generation and initial analysis of more than 15,000 full-length human and mouse cDNA sequences. Proc Natl Acad Sci U S A 99:16899-16903

11. Masuda M, Tsunoda M, Yusa Y, Yamada S, Imai $\mathrm{K}$ (2002) Assay of catechol- $O$-methyltransferase activity in human erythrocytes using norepinephrine as a natural substrate. Ann Clin Biochem 39:589-594

12. Harrison GP, Mayo MS, Hunter E, Lever AM (1998) Pausing of reverse transcriptase on retroviral RNA templates is influenced by secondary structures both $5^{\prime}$ and $3^{\prime}$ of the catalytic site. Nucleic Acids Res 26:3433-3442 